\title{
Нове в лікуванні дітей із розладами аутистичного спектру (огляд літератури)
}

\author{
В.І. Боброва, О.В. Боброва \\ Національний університет охорони здоров'я України імені П.Л. Шупика, Київ, Україна
}

Анотація. Стаття присвячена пацієнтам із розладами аутистичного спектру. Описана історія розвитку діагнозу «аутизм», клінічна картина і можливості лікування таких дітей, включаючи клітинну терапію.

Ключові слова: розлади аутистичного спектру, аутизм, клітинна терапія, фетальні стовбурові клітини.

\section{Актуальність проблеми}

Розлади аутистичного спектру (РАС) - гетерогенна група порушень нейророзвитку, що включають різні нозологічні дефініції (синдроми Каннера і Аспергера, високофункціональний аутизм, інфантильний психоз, атиповий дитячий психоз, дитячий дезінтегративний розлад, а також безліч хромосомних і генетичних синдромів), що характеризуються тріадою порушень: якісними порушеннями соціальної взаємодії та спілкування, стереотипною поведінкою і неспецифічними проблемами [1, 2].

Термін «аутизм» як негативний синдром при шизофренії запропонований швейцарським психіатром Ойгеном Блейлером (Eugen Bleuler) у 1911 р. Вхід хворого у світ фантазій він позначив терміном «аутизм» і діагностував його у будьяких «психотиків» ендогенного й органічного походження. У Росії у 1926 р. Г.Ю. Сухарєвою описана клінічна картина «шизоїдної психопатії» у дитячому віці, яка близька до опису «аутистичної психопатії» Ганса Аспергера (Hans Asperger) у 1944 р. [3, 4].

Лео Каннер (Leo Kanner) у 1943 р. вперше описав ранній дитячий аутизм як окреме захворювання на групі 11 пацієнтів 3 «аутистичною самотністю і нав'язливим прагненням до одноманітності $з$ народження». У 1949 р. L. Kanner писав: «Я не вірю, що існує якась вірогідність того, що ранній дитячий аутизм в майбутньому буде відділений від шизофренії». 3 часу опису аутизму L. Kanner ведуться безперервні дискусії про його нозологічну приналежність [5, 6].

Майкл Раттер (Michael Rutter) з робочою групою Всесвітньої організації охорони здоров'я в 1968 р. намагався розділити дитячий аутизм і дитячу шизофренію, що знайшло відображення у Міжнародній класифікації хвороб IX перегляду. Термін «аутизм» у спеціальній літературі відносять до «аутистичного розладу», який визначений у Діагностичній та статистичній настанові з психічних розладів (Diagnostic and Statistical Manual of mental disorders - DSM) IV перегляду, а також до «розладів аутистичного спектру» $[7,8]$.

У 2019 р. описаний «континуум аутистичних розладів» і дитячої шизофренії, прийнятий у світі $[5,9,10]$.

На жаль, частота виявлення аутизму в останні роки значно зросла. Так, у 2000 р., за даними Всесвітньої організації охорони здоров'я, поширеність аутизму становила 5-26 випадків на 10 тис. дитячого населення. У 2020 р. Центрами з контролю та профілактики захворювань США (Centers for Disease Control and Prevention - CDC) опубліковано нову статистику: РАС відмічають у кожної 54-ї дитини, що на 10\% більше, ніж за статистикою 2018 р. [11].

На сьогодні у 1-3\% всіх дітей на планеті відмічають аутизм.

Загальновизнаної концепції етіології РАС у світі не існує. $\epsilon$ різні гіпотези етіології РАС, як соціальні, психологічні, так і біологічні, і навіть екологічні. Слід мати на увазі, що існуючі гіпотези не виключають одна одну і, швидше за все, описують порушення у різних системах. Крім того, причина/причини РАС можуть полягати в одночасному впливі різних етіологічних факторів, на- приклад генетичній схильності у поєднанні з дією будь-якого вірусу або мікроорганізму на певній стадії внутрішньоутробного розвитку.

До факторів ризику виникнення аутизму належать:

- наявність родичів із діагнозом «шизофренія» або іншими психічними захворюваннями;

- недоношеність;

- вік батьків >40 років;

- проживання у великих мегаполісах (забрудненість навколишнього середовища).

В останнє десятиліття в цій галузі досягнуті значні успіхи. 3окрема досягнення в сфері генетики дозволили по-новому осмислити молекулярні і клітинні механізми цієї патології. У той самий час виникають нові питання, в тому числі зв'язок між генотипом і фенотипом. Внесок факторів навколишнього середовища за допомогою адитивного або мультиплікативного ефекту потребує подальшого вивчення.

Етіологію аутизму вдається встановити у $40 \%$ випадків, причина інших 60\% - невідома (рисунок).

Рисунок Причини аутизму

\begin{tabular}{|c|c|c|}
\hline \multicolumn{3}{|c|}{ Причини аутизму } \\
\hline$\downarrow$ & $\downarrow$ & $\downarrow$ \\
\hline $\begin{array}{c}\text { Екзогенні: } \\
\text { тератогенний вплив } \\
\text { (віруси, радіація, травма, } \\
\text { гостра асфіксія, } \\
\text { інтоксикація) }\end{array}$ & $\begin{array}{c}\text { Ендогенні: } \\
\text { спадкові причини і вплив } \\
\text { найближчого оточення } \\
\text { (характер виховання } \\
\text { дитини, ступінь їі } \\
\text { депривації) }\end{array}$ & $\begin{array}{c}\text { Генетичні та хромосомні } \\
\text { аномалії }\end{array}$ \\
\hline
\end{tabular}

На сьогодні знати наперед, що у дитини розвинеться РАС, неможливо. Усі програми розглядають питання щодо можливого варіанту розвитку РАС. Ці програми проводять з віку 18 міс. Раса, соціальна приналежність, виховання дитини не чинять істотного впливу на розвиток аутизму.

Серед хлопчиків поширеність захворювання вища, ніж серед дівчаток, - 1:4, але чим тяжчий аутизм, тим ця поширеність менша і становить 1-2,5.

Відповідно до сучасних уявлень, за класифікацією DSM V перегляду, існують дві категорії критеріїв для встановлення діагнозу РАС:

\section{Основні ознаки:}

1. Порушення соціальної комунікації (діти з аутизмом мають порушення мовлення).

2. Стереотипна поведінка.

3. Сенсорні порушення.

\section{Додаткові ознаки:}

- розумова відсталість (у 70\% дітей);

- епілептиформні прояви (у 10\% дітей);

- мікроаномалії і вади розвитку. 


\section{На що необхідно звернути увагу батькам?}

Існує скринінгова анкета М-СНАТ, яка заповнюється протягом 7 хв, і якщо виявляють якісь ознаки порушення, вони слугують сигналом, щоб відправити дитину на подальше дообстеження до психіатра.

Вищезазначене робить все більш актуальною цю проблему і потребує розробки нових методів психологічної, соціальної та структурної корекції патології.

Чим раніше встановлений діагноз і чим раніше розпочнеться реабілітація, тим більше шансів не дати хворобі поглинути розум дитини.

Не слід відкладати консультацію з фахівцями, якщо у дитини наявні кілька з нижченаведених ознак:

- дитина відсторонена, ігнорує матір, не реагує на прохання;

- не відгукується на своє ім'я;

- не вміє гратися іграшками за призначенням, не розвиваються сюжетні ігри;

- не грає з іншими дітьми;

- у дитини істерики, напади агресії або самоагресії;

- дитина не дивиться в очі;

- однотипні рухи руками, розгойдування;

- починала говорити перші слова, але мова пропала;

- не промовляє слова, не користується жестами;

- не розуміє оточуючих;

- ходить на носочках;

- боїться сильних звуків;

- каже одні й ті самі слова, фрази;

- каже про себе у третій особі;

- виявляються порушення сну;

- має місце затримка мови.

\section{Що треба робити, якщо є}

\section{підозра, що у дитини аутизм?}

Треба переконатися, чи він існує. Для діагностики $\epsilon$ багато методик, які апробовані і давно використовуються, наприклад спеціальний опитувальник для встановлення діагнозу ADAS. Опитування проводить лікар-психіатр.

Алгоритм обстеження дитини наступний:

1. Первинна консультація (збір скарг, анамнезу, оцінка родоводу і фенотипу).

2. Загальноклінічне обстеження (клінічний аналіз крові, сечі, біохімічний профіль, копрограма, кал на дисбактеріоз і т.д.).

3. Цитогенетичне дослідження лімфоцитів периферичної крові, визначення хромосомної нестабільності, молекулярноцитогенетичні методи.

4. Виявлення метаболічних порушень.

5. Інфектологічне обстеження (бактеріологічне, вірусологічне).

6. Імунограма.

7. Функціональні методи дослідження (ультразвукове дослідження, ядерна магнітно-резонансна томографія головного мозку, електроенцефалографія, реоенцефалографія, ехокардіографія, електроміографія, магнітно-резонансна спектроскопія головного мозку).

8. Молекулярно-генетичні методи.

Програма обстеження підбирається індивідуально!

До видів лікування, що застосовують у дітей із РАС, належать нейропсихологічна корекція, психотерапія, соціотерапевтичні заняття, фізіотерапія, лікувальна педагогіка, логопедичні заняття, трудотерапія, хелатування, медикаментозне лікування, дієтотерапія, анімалотерапія.

Сьогодні в усьому світі все частіше вдаються до застосування стовбурових клітин в лікуванні таких пацієнтів. Важливо відзначити, що своєчасно розпочате лікування аутизму стовбуровими клітинами, поки йде розвиток головного мозку, $є$ запорукою успішного розвитку дитини.

Клінічні випробування трансплантації стовбурових клітин при РАС мають життєво важливе значення для підтвердження безпеки (в першу чергу) й ефективності клітинної терапії.

На сьогодні проведено декілька клінічних випробувань, що продемонстрували безпеку та ефективність лікування дітей із РАC. A. Sharma та співавтори (2013) провели відкрите дослідження, яке підтвердило концепцію застосування трансплантації аутологічних мононуклеарних клітин кісткового мозку (Bone Marrow Mononuclear Cells - BMMNC) у 32 дітей (середній вік на момент втручання 10,5 року, співвідношення хлопчики/ дівчатка - 3:1) з підтвердженим діагнозом «аутизм» [12]. Протокол включав інтратекальне введення стовбурових клітин з наступною ерготерапією, сенсорним інтегративним підходом, а також заняття з логопедом, психологом і дієтичні рекомендації.

Фракція мононуклеарних клітин являє собою гетерогенну суміш, що складається з ендотеліальних клітин-попередників HSCs (hematopoietic stem cells) тa MSCs (mesenchymal stem cells), а також мультипотентних дорослих клітин-попередників. Ці клітини відокремлювали від аспірату кісткового мозку, підраховували маркером CD34+ і перевіряли на життєздатність. У той самий день клітини вводили інтратекально і внутрішньовенно. Для визначення безпеки трансплантації стовбурових клітин відстежували довгострокові побічні ефекти. Відзначено незначні побічні ефекти (блювання, нудота, біль при ін'єкції). Повідомлялося, що ці події були пов'язані з процедурою введення, а не $з$ клітинною трансплантацією. У 3 пацієнтів відмічали гіперактивність і напади, що розцінили як небажане негативне явище, пов'язане 3 клітинною процедурою. Пацієнтів оцінювали за шкалою Indian Scale for Assessment of Autism (ISAA) і відзначили покращення у сфері соціальної поведінки (покращення зорового контакту, соціалізації і спілкування з іншими, когнітивних аспектів (увага, концентрація), а також у мовній сфері (скорочення ехолічної мови, покращення здатності підтримувати розмову), відзначали зменшення стереотипних повторювальних рухів.

Продемонстровано підвищене поглинання ${ }^{18} \mathrm{~F}$-фтордезоксиглюкози в лобній ділянці, мозочку, гіпокампі, парагіпокампі і медіальній скроневій частці через 6 міс після клітинної терапії [13].

Проведено пілотне дослідження 45 дітей (39 хлопчиків і 6 дівчаток, середній вік 6,9 року) із РАС, в якому оцінювали безпеку і вплив фетальних стовбурових клітин (ФСК) на дітей із аутизмом.

Виготовляли препарати у формі суспензії кріоконсервованих стовбурових клітин. Для цього в умовах операційної з дотриманням правил асептики та антисептики отримували ембріофетальний матеріал строком 7-9 тиж гестації: фетуси, загиблі в результаті медичного аборту у випадках, коли вагітність переривали за соціальними показниками за відсутності патології розвитку чи інфікованості, за наявності інформованої згоди жінки. Суспензії, що містять стовбурові клітини, зберігали в кріобанку з рідким азотом при температурі $-196{ }^{\circ} \mathrm{C}$. Жінки-донори і зразки плода протестовані на бактеріальні, грибкові та вірусні інфекції та паразити. У 1-й день суспензію вводили внутрішньовенно, на 2-й день - у підшкірну жирову тканину передньої черевної стінки. У дітей із РАС, які отримували ФСК, не виявлено побічних ефектів. Ранні ефекти післяклітинної трансплантації полягали у поліпшенні зорового контакту, апетиту і соціалізації. Лікування оцінювали за даними опитувальників АBC (Autism Behavior Checklist) i ATEC (Autism Treatment Evaluation Checklist) при подальшому спостереженні протягом 6 і 12 міс. Відзначено покращення комунікабельності, когнітивних здібностей і поведінки. Слід зазначити, що імунологічні результати пре- та післяклітинного лікування показали покращення клітинного імунітету через значне збільшення CD3+ ${ }^{+}$-лімфоцитів і CD4+ а також зниження кількості CD19+ В-лімфоцитів після лікування. Лікування мало безпечний перебіг і добре переносилося. Шляхи введення (внутрішньовенний та підшкірний) обрані з урахуванням їх меншої інвазивності, на думку авторів [14]. 
У клітинній суспензії міститься величезна кількість біологічно активних речовин, цитокінів, факторів росту, які сприяють активації власних біологічно активних речовин. Введення ФСК чинить цілеспрямований вплив на функціональні структури головного мозку, сприяє поліпшенню міжсинаптичних зв'язків між нейронами, відновленню балансу нейротрансмітерних систем мозку в результаті синтезу нейромедіаторів, покращує нейромедіаторну передачу по аксонах і відновлює проведення нервових імпульсів по збережених нервових волокнах. Як наслідок, вираженість патологічного процесу зменшується, порушені неврологічні функції можуть відновлюватися, знижується психологічний дефіцит, покращуються когнітивні функції, якість життя і соціальна адаптація дітей.

\section{Як працюють стовбурові клітини при РАС?}

1. Заміщення пошкоджених клітин стовбуровими клітинами.

2. Спонукання пошкоджених клітин до регенерації (одужання).

3. Активація різних факторів росту.

\section{Який механізм дії стовбурових клітин?}

Введення ФСК зумовлює відновлення балансу нейротрансмітерних систем головного мозку в результаті синтезу нейромедіаторів, покращення нейромедіаторної передачі по аксонах і відновлення проведення нервових імпульсів по збережених нервових волокнах.

Позитивно впливають ФСК і на фізичний розвиток дитини, коригують дисфункцію різних систем організму, зокрема імунної та шлунково-кишкового тракту.

У результаті лікування аутизму стовбуровими клітинами дитина стає більш контактною, адаптованою до соціального середовища, посидючою, значно покращується мова. Стовбурові клітини сприяють гармонійному фізичному розвитку дитини.

В Україні існують клініки, які пропонують лікування різних захворювань за допомогою стовбурових клітин. Одна з таких клінік — «EmCell» (заступник головного лікаря - Н.С. Сич*).

\section{Список використаної літератури/References:}

1. Porokhovnik L.N., Lyapunova N.A., Kozlovskaya G.V. et al. (2015) Ribosomal genes as a factor modeling the development of autism and schizophrenia. Modern therapy in psychiatry and neurology, 1: 41-47. (In Rus.).

2. Simashkova N.V. (Ed.) (2013) Autism spectrum disorders in children. Scientific and practical guidance. Author's Academy, Moscow, 264 p. (In Rus.).

\section{Відомості про авторів:}

Боброва Валентина Іванівна - доктор медичних наук, професор кафедри медицини невідкладних станів Національного університету охорони здоров'я України імені П.Л. Шупика, Київ, Україна.

Боброва Олена Володимирівна — професор, доцент кафедри кардіології Національного університету охорони здоров'я України імені П.Л. Шупика, Київ, Україна.

Адреса для кореспонденції:

Боброва Валентина Іванівна

04112, Київ, вул. Дорогожицька, 9

E-mail: valenta030245@gmail.com
3. Clayton P.J., Fatemi S.H. (2008) The medical basis of psychiatry. Totowa, 72 p.

4. Kanner L. (1943) Autistic disturbances of affective contact. Nerv. Child., 2-3: 217-250.

5. Kanner L. (1949) Problem of nosology and psychodynamics of early infantile autism. Am. J. Orthopsychiatr., 19(3): 415-420.

6. Tiganov A.S., Bashina V.M. (2005) Contemporary Approaches to Understanding Childhood Autism. J. Neurol. Psychiatrist., 105: 4-13. (In Rus.).

7. Nikolskaya O.S., Baenskaya E.R., Liebling M.M. (2007) The Autistic Child. Ways to help. Terevinf, Moscow, 243 p. (In Rus.).

8. Rutter M. (1968) Concepts of autism: A review of research. Child Psychology \& Psychiatry \& Allied Disciplines, 9(1): 1-25.

9. Simashkova N.V. (2012) Review — response to the case study of the Royal Society of Medicine. «Missed diagnosis is a lost life». Modern therapy in psychiatry and neurology, 1: 32-34. (In Rus.).

10. Owen M.J., O'Donovan M.C., Thapar A., Craddock N. (2011) Neurodevelopmental hypothesis of schizophrenia. Br. J. Psychiatr., 198(3): 173-175.

11. Mukayetova-Ladinskaya E.B.,Simashkova N.V., Mukayetova M.S. et al. (2018) Autism spectrum disorders in children and adults: approaches to the problem in different countries. S.S. Korsakov Journal of Neurology and Psychiatry, 118(12): 92-99. (In Rus.).

12. Sharma A., Gokulchandran N., Sane H. et al. (2013) Autologous bone marrow mononuclear cell therapy for autism: an open label proof of concept study. Stem Cells Int., 2013: 623875.

13. Sharma A.K., Gokulchandran N., Kulkarni P.P. et al. (2020) Cell transplantation as a novel therapeutic strategy for autism spectrum disorders: a clinical study. Am. J. Stem. Cells, 9(5): 89-100.

14. Bradstreet J.J., Sych N., Antonucci N. et al. (2014) Efficacy of fetal stem cell transplantation in autism spectrum disorders: an open-labeled pilot study. Cell Transplant., 23(1 Suppl.): S105-S112.

\section{New in treatment of children with autism spectrum disorders (literature review)}

\section{V.l. Bobrova, O.V. Bobrova}

Shupyk National Healthcare University of Ukraine, Kyiv, Ukraine

Abstract. The article is dedicated to patients with autism spectrum disorders, describes the history of the diagnosis of "Autism», the clinical picture and treatment options for such children, including cell therapy. Key words: autism spectrum disorders, autism, cell therapy, fetal stem cells.

\section{Information about the authors:}

Bobrova Valentyna I. - Doctor of Medical Sciences, Professor of the Department of emergency medicine of the Shupyk National Healthcare University of Ukraine, Kyiv, Ukraine.

Bobrova Olena V. - Professor, Associate Professor of the Department of Cardiology of the Shupyk National Healthcare University of Ukraine, Kyiv, Ukraine.

Address for correspondence:

Valentyna Bobrova

04112, Kyiv, Dorogozhytska st, 9

E-mail: valenta030245@gmail.com

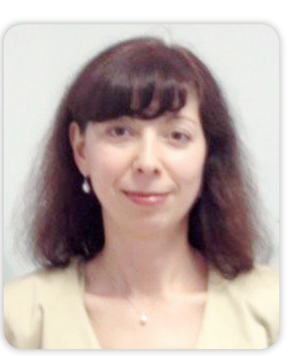

*(ич Наталія Сергіївна — невролог, дитячий невролог, кандидат медичних наук (кандидатська дисертація на тему «Когнітивні порушення у хворих в гострому періоді інфаркту мозку», 2010 р.). Має 15-річний досвід роботи у сфері клітинних технологій. Автор та співавтор 45 патентів і >110 наукових статей, опублікованих у міжнародних журналах. Розробник внутрішніх протоколів лікування різних неврологічних захворювань за допомогою ФСК. Неодноразово брала участь у міжнародних конференціях із усною та стендовою доповіддю (Марокко, Mарракеш, 2011 p.: «Fetal Stem Cells in Post-Stroke Cognitive Deficits Embryonic Tissues Center Em Cell»; Угоршина, Будапешт, 2011 р.: "Clinical effect of fetal stem cells in multiple sclerosis»; Великобританія, Лондон, 2012 р.: «The state of neuroaminoacids in patients after a traumatic brain injury with convulsive syndrome»; Румунія, Бухарест, 2013 p.: «Efficacy of fetal stem cell transplantation in autism spectrum disorders: a pilot study»; (СН-Дiє20, (ША, 2013 p.: "Cognitive and neuroimmune disorders in patients in the acute period of ischemic stroke», (ан-Дiє20, (ША, 2018 p.: «Efficacy of fetal stem cell treatment for Parkinson's Diseases»).

Має Подяку головного лікаря міської клінічної лікарні № 8 м. Запоріжжя (2004 р.), Подяку Католицької черкви штату Каліфорнія (Сан-Дієго, (ША, 2019 р.), Подяку президента громадської організації «Громадські ініціативи охорони здоров'я «здорове людство» (2021 р.), Подяку державної адміністрації Дарницького району в місті Києві (2021р.).

Проводила вебінари на такі теми: «Майбутнє медицини за стовбуровими клітинами», «Нове в лікуванні дітей з розладом аутистичного спектра».

Член Alzheimers's association (3 2017 p.), Multiple Sclerosis Association of America (3 2017 p.), American Society of Gene + Cell Therapy (3 2020 p.). 